\title{
INTERNATIONAL SCIENTIFIC CONFERENCE "ART HISTORY IN THE CONTEXT OF OTHER SCIENCES IN RUSSIA AND ABROAD: PARALLELS AND INTERACTIONS"
}

The International Scientific Conference "Art History in the Context of Other Sciences in Russia and Abroad: Parallels and Interactions" was held 23-28 April 2017 in the Schnittke Moscow State Institute of Music. The Russian Foundation for the Basic Research Conference has supported the Project (the Author of the Conference Project and the Chairman of its Organizing Committee - Grigoriy R. Konson; Grant Number 17-04-14080). Over 90 researchers, who arrived in Moscow from the 54 Universities of Belarus, China, Germany, India, Italy, Mongolia, the UK, Ukraine, the USA attended a scientific forum.

All the sessions of the Conference were broadcast on the Internet ${ }^{1}$. International teleconferences were organized during the sessions. The national educational television channel "Prosvescheniye (Enlightenment)" as well as Russian and foreign academic periodicals supported the Conference.

The concept of parallels and interactions in interdisciplinary spheres of knowledge was identified from the historical and theoretical position.

The Education and Science were subjects of Plenary Sessions (Fig. 1). The Doctor of Art History, Associate Professor of the Russian Music History Department, Senior Researcher of the Kvitka Research Center of Folk Music, the Tchaikovsky Moscow State Conservatory, Deputy Chief of the Humanities and Social Sciences Department, Russian Foundation for Basic Research, Nikolai G. Denisov has opened it.

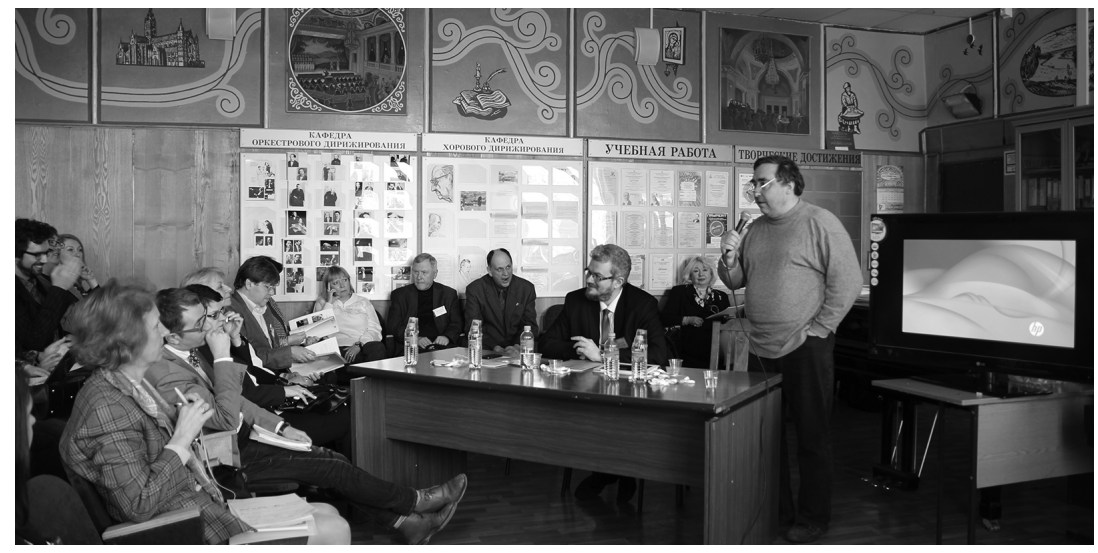

Fig. 1. Plenary Sessions

${ }^{1}$ See e.g.: https://www.youtube.com/watch?v=B7yPUldcVPo 
Much attention was attracted here by the synthesis reports:

- "About Main Tendencies of Preparing Research Assistants in Russia (in Comparison with Anglo-Saxon Academic Experience)" by Grigoriy R. Konson - Doctor of Art History, Head of Department of Applied Doctoral Studies and Preparation of Research Assistants, Professor of Department of Sociology and Philosophy of Culture, Russian State Social University, Laureate of Russian and International Competitions and Festivals, Member of the Federal Register of Experts in the Field of Science and Technology of the Ministry of Education and Science of the Russian Federation, Member of the Russian Council Advisory Board;

- "Classical University in the Era of New Information Technologies: the St. Petersburg State University Experience in the Context of Development of the World Leading Universities" by Olga V. Popova - Doctor of Political Sciences, Professor, Head of the Department of Political Institutions and Applied Political Researches, the St. Petersburg State University, Deputy Editor-in-Chief of Scientific Journal "Political Expertise: POLITEKS";

- "On Special Features of the Art Academic Publications in International Data Bases "Scopus" and "WoS"” by Olga V. Kirillova - PhD in Technics, President of the Association of Academic Editors and Publishers (AAEP), Director of Training and Consulting Center, Academy AAEP / Non-Profit Partnership "National Electronic and Information Consortium" (NP "NEICON"), Authorized Expert and Consultant of "Scopus";

- "Russian Art Education in the Bologna Process (on the Basis of Analyzing the Classical University Tradition of Saint-Petersburg)" by Svetlana M. Gracheva - Doctor of Art History, Professor, Dean of the Faculty of the Theory and History of Fine Arts, I. Repin St. Petersburg State Academy Institute of Painting, Sculpture and Architecture, Russian Academy of Arts;

- "Challenges of Informational Civilization vs Humanist of the XXI century" by Galina $Y u$. Nikiporets-Takigawa - PhD in Philology, PhD in Russian Studies, Professor of the Slavonic Researches Department, the Cambridge University, Head of the Department of Political Science and International Relations, Dean of the Faculty of Humanities, the Russian State Social University, in cooperation with Gennadiy P. Otyutskiy - Doctor of Philosophy, Professor, of the Social Philosophy, Political Science and International Relations Department, the Russian State Social University.

In parallel, the topic of education was considered in the special spheres of knowledge:

- Educational-Ethical: "Problems of Establishing Academic Reputation (on the Basis of Analysis of Humanities and Social Sciences PhD Thesis and Scholar Publications)" by Andrey A. Rostovtsev - Doctor of Physics and Mathematics, Leading Researcher of Laboratory No 5 "Quantum Physics and Information", the Institute for Information Transmission Problems (the Kharkevich Institute) of the Russian Academy of Sciences, Co-Founder of the Volunteer Network Community "Dissernet";

- Theatrical: "Theatre Art Education in Russia and Abroad: Parallels and Interactions" by Grigoriy A. Zaslavsky - PhD in Philology, Laureate of the Moscow Government Award, the Rector of the Russian State Institute of Theatre Arts "GITIS" (Fig. 2);

- Musical Performing Art: "About Some Trends of Modern Concert Management and Musical Education in Russia and Abroad (on the Basis of Piano Art Experience)" by Ekaterina V. Mechetina - Soloist of the Moscow State Philharmonic Society, Teacher Assistant of Special Piano Department headed by Professor Mikhail S. Voskresensky, the Tchaikovsky 
Moscow State Conservatory, Laureate of International Competitions, Prizewinner of the President of the Russian Federation Award (2011), Honored Artist of the International Union of Musicians (2016), Member of the Presidium of the President of the Russian Federation Council for Culture and Art, Chairman of the International Youth Art Festival "Green Noise";

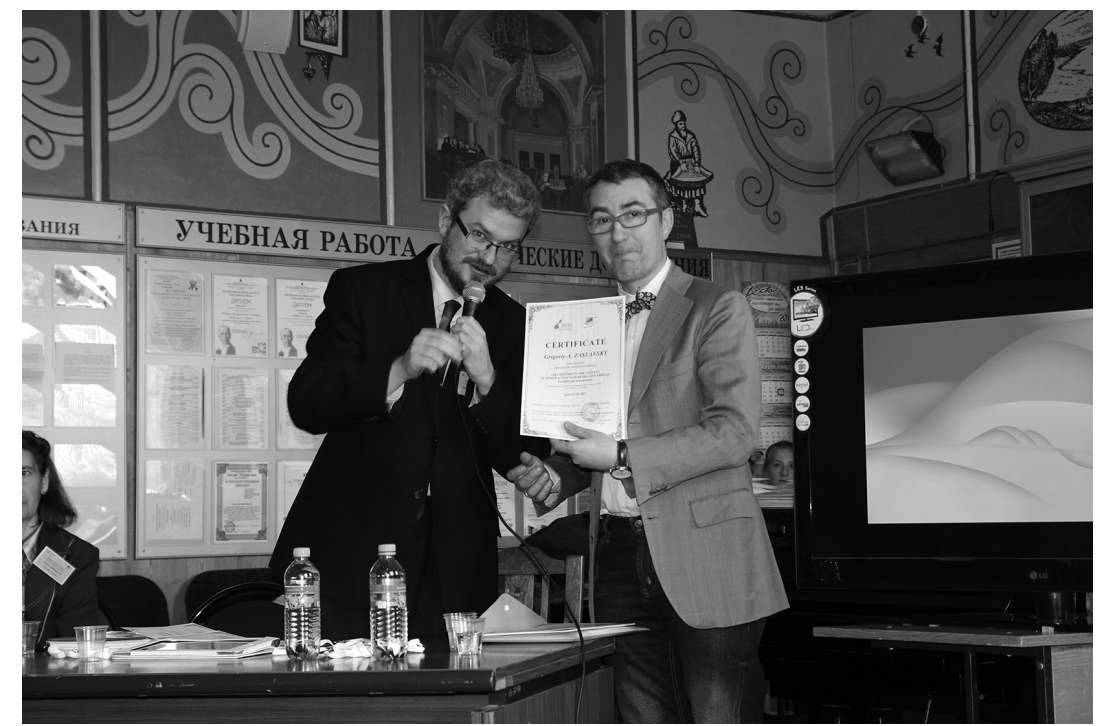

Fig. 2. Grigoriy R. Konson (left) and Grigoriy A. Zaslavsky

- Psychological and Pedagogical: "The Bologna Process and National Musical Education: Integration or Degradation?" by Olga L. Berak - PhD in Education, Professor of the Music Theory Department, the Gnesins Russian Academy of Music, "New Psychological and Pedagogical Strategies in Concert Musician Education” by Olga M. Bazanova - Doctor of Biology, Professor, the Sholokhov Moscow State University for Humanities, Chief Research Scientist, the Novosibirsk State University, Chief Researcher of Laboratory of Affective, Cognitive and Translational Neuroscience, the State Scientific Research Institute of Physiology \& Basic Medicine, Siberian Branch of the Russian Academy of Sciences, in cooperation with Tatiana I. Petrenko Associate Professor, the Special Piano Department, the Schnittke Moscow State Institute of Music, Head of the Subject Committee of General Piano, the Central Music School of the Tchaikovsky Moscow State Conservatory;

- Philological: "Philological Education in Russia and Abroad: Innovative Techniques as Factor of Changing Main Trends of University Education” by Marina V. Nevskaya Associate Professor, Rector Council Advisor, Dean of Faculty of Linguistics, the Russian State Social University;

- Musicological: "Prospect of Convergence of Russian and World Musicological Traditions: Analysis Experience” by Tatiana I. Naumenko - Doctor of Art History, Professor, the Head of the Music Theory Department, Vice-Chairman of the Council for Ph.D. Theses D 210.012.01 of the Gnesins Russian Academy of Music.

The study of these areas was continued on the next days of the conference and was characterized by the integration of different disciplines of knowledge. One of the most 
popular fields of science at the conference was the Psychology that naturally interacts with other disciplines:

- Philology: "Fantomas as Inter-Media Mythological Character" by Natalia T. Pakhsarian - Doctor of Philology, Professor of the Foreign Literature History Department of the Philological Faculty at the Lomonosov Moscow State University, Leading Researcher of the Literary Criticism Department at the Institute of Scientific Information on Social Sciences of the Russian Academy of Sciences, President of the Russian Society for Eighteenth-century Studies (Division of the International Society for Eighteenth-century Studies - ISECS), "About Typical Psychic Conditions in Characters' Behavior in L.N. Tolstoy's, A.P. Chechov's and I.S. Turgenev's Works” by Vyacheslav I. KazarenkovDoctor of Pedagogical Sciences, Professor, the Social and Differential Psychology Department, Head of the Educational Art School, RUDN University;

- Psychology with its Communicative Aspect: "Musical Experience as the Basis for the Music Therapy Effectiveness” by Alla V. Toropova - Doctor of Pedagogical Sciences, Professor of the Department of Methodology and Techniques of Music Education, Moscow Pedagogical State University, in cooperation with Wolfgang Mastnak - Dr. h. c., Professor, the University of Music and Performed Arts (Munich, German Federal Republic);

- Music Psychology and its study, increasing of meaning and correlation with the theory of information: "Musical Synesthetic and Non-Classical Art History" of Nina P. KolyadenkoDoctor of Art History, Ph.D. in Philosophy, Professor, the Head of History, Philosophy and Art History Department, Academic Secretary of the Council for Ph.D. Theses D 210.011.01, the Glinka Novosibirsk State Conservatory, "Possible" and "Impossible" in Music: Psychology of Perception of the New and Information Theory" by Vladimir P. Ryzhov - Doctor of Physics and Mathematics, Professor of the Radiotechnics Theoretical Basics Department, the Taganrog Institute of the Technology of South Federal University, Professor of the Audio Engineering and Information Technology Department, the Rachmaninov Rostov State Conservatory, Honored Worker of Higher Professional Education of Russia, Honored Worker of the Russian Musical Society.

During the other days of the conference the field of research included Painting and Architecture: "The "Crucifixion" Topic in Russian Sacral Plastics. Stylistic and Iconography Issues" by Maria A. Burganova - Doctor of Art History, Professor of the MonumentalDecorative Sculpture Department, the Stroganov Moscow State Art Industrial Academy, Editor-in-Chief of Scientific and Analytical Journal "Burganov House. The Space of Culture", Art and Literature Scientific and Analytical Journal "Texts", Full Member of Russian Academy of Arts, Honored Artist of Russia, "Sociocentric vs Anthropocentric Principles in Architecture: History and Modern Research Approaches” by Boris N. RyzhovDoctor of Psychology, Professor, Head of the Development and Social Psychology Department, the Moscow City Pedagogical University, Editorial Board Chairperson of the Scholar Journal "System Psychology and Sociology", Laureate of the Moscow Government Award (2009), Honored Worker of Higher Professional Education of the Russian Federation;

- Literature Study: “"Dialogues” of Francesco Petrarca and Their Textual and Visual Interpretation in the Reformation Era: Common and Special Features in Modern European and Russian Approaches” by Nina I. Devyataikina - Doctor of History, Professor, the 
Lecturing History Methods Department of the Moscow State Pedagogical University, the Homeland History and Culture Department of the Yuri Gagarin Saratov State Technical University, Member of the Central Council of the All-Russian Social Movement of Creative Teachers "Researcher", Scientific Supervisor of Lyceum № 1561 (Moscow), "Interaction Prospects of West-European and Russian Libretology" by Anna V. Stetsenko Second-year Graduate Student of the Languages and Literature Division of the Comparative Studies Department, the Rome University "Tor Vergata" (Supervisors: Professor Nicoletta Marcialis, PhD in Art History Grigoriy I. Gansburg).

Musicology was, of course, the fundamental area of study analysis. The aspects it concerned were:

- Western European Baroque music: "Baroque Music as a Problem of the Contemporary Russian Musicology" by Yury S. Bocharov - Doctor of Art History, Leading Researcher of the Center of Studies in Historical Musicology, the Tchaikovsky Moscow State Conservatory, Editor-in-Chief of Starinnaya Muzyka [Early music] journal, "Life and Education of Young Singers in French Ma trises of the XVII-XVIII centuries" by Valery V. Berezin - Doctor of Art History, Professor of the History of Foreign Music Department, the Tchaikovsky Moscow State Conservatory;

- Russian Documentaries: "Academic Activity of Yu.N.Tyulin and Russian Musicology" by Arkady I. Klimovitsky - Doctor of Art History, Professor of the Music Theory Department at the Rimsky-Korsakov St. Petersburg State Conservatory, Chief Researcher, the Russian Institute of Art History, Honored Artist of the Russian Federation, "Creative Activities of A.P rt and V.Martynov: Reconstruction of Medieval understanding of Music Art in Terms of Quadrivium" by Vyacheslav N. Grachev - Doctor of Art History, Professor of the Military Institute (Military Conductors) of the Military University, Honored Worker of Higher Professional Education of the Russian Federation;

- Musical Theatre and Theatricality: "Carl Dahlhaus: Musical Drama as Symphonic Opera” by Stephan B. Naumovich - Ph. D. in Art History, Author-Coordinator of the Project "The Russian Dahlhaus" (German Federal Republic, the Russian Federation), "Theater and Music: Aesthetic vs Interactive (on the basis of Analysis of Modern Trends in Art of Russia and Other Countries)" by Ludmila S. Bakshi - Ph. D. in Art History, Professor of the Department of Philosophy, History and Theory of Culture and Arts, the Schnittke Moscow State Institute of Music, Laureate of All-Russian and International Awards;

- The Folklore of Different Countries: "Typical Musical Genres of the Former Soviet Union Peoples" by Vyatcheslav M. Shchurov - Doctor of Art History, Professor of the History of Russian Music Department, Honored Artist of Russia, the Tchaikovsky Moscow State Conservatory, "High Spirituality as Basis of Musical Tradition of the Bukhara and Andalusian Jews (on Materials of Shashmakom and Noobs)" by Violetta N. YunusovaDoctor of Art History, Professor of the History of Foreign Music Department, the Tchaikovsky Moscow State Conservatory, "About Development of the Eastern Composer Schools Theory (in the Case of Activities of the Tajik Composer Ziyodullo Shakhidi)" by Marina N. Drozhzhina - Doctor of Art History, Professor of the Music Education Department, the Glinka Novosibirsk State Conservatory, "Spiritual Modus of Traditional Music Performing in India” (Master Class) by Amir Khan (India) - Bollywood Singer and Tabla Percussionist; 
- Theory of Musical Performing Art: "Creative Freedom of Performing Musician as the Subject for Discussion” by Boris B. Borodin - Doctor of Art History, Head of the Theory and History of Performance Arts Department, the Musorgsky Ural State Conservatory, Prizewinner of the Russian Performance Art Fund, “Johann Sebastian Bach: Meter and Articulation as the Creativity” by Mikhail A. Arkadyev - Doctor of Art History, Professor and Supervisor of the Music College, the Hunan Institute of Science and Technology (China), "About Leagues in Clavier Works of J.S.Bach, or is it Always Possible to Trust the Urtext” by Vladimir A. Shekalov - Doctor of Art History, Professor of the Musical Art Department, the Vaganova Ballet Academy;

- Professional Creativity: "Musical and Historical Process and Change of Composer Generations (in the Case of Romanticism Art)" by Grigoriy I. Hansburg - Ph.D in Art History, Director of the Musicology Institute (Kharkov, Ukraine), Head of the Schubert Society in Kharkov;

- Rock, Pop, Jazz, Musical: “Art-rock as Reflection of Style Dialogues” by Valery N. Syrov - Doctor of Art History, Professor, Head of the Music Theory Department, the Glinka Nizhniy Novgorod State Conservatory, Honored Artist of Russia, Chairman of the Council for Ph.D. Theses (K 210.030.01) at the Glinka Nizhniy Novgorod State Conservatory, "Russian Rock as a Reflection of Postmodernism" by Anatoly M. Tsuker Doctor of Art History, Professor, Honored Artist of Russia, Chairman of the Council for Ph.D. Theses (D 210.016.01), the Rachmaninov Rostov State Conservatoire, Chairman of the Board of the Rostov Branch of the Union of Composers of Russia, "Contemporary Pop Music in Russia and Abroad: Crisis vs Perspectives” by Grigoriy R. Konson - Doctor of Art History, Head of Department of Applied Doctoral Studies and Preparation of Research Assistants, Professor of Department of Sociology and Philosophy of Culture, Russian State Social University, Laureate of Russian and International Competitions and Festivals, Member of the Federal Register of Experts in the Field of Science and Technology of the Ministry of Education and Science of the Russian Federation, Member of the Russian Council Advisory Board, in cooperation with Maria L. Katz - Secondyear Undergraduate of the Department of Sociology and Philosophy of Culture, the Russian State Social University, the $1^{\text {st }}$ finalist of the International Contest "Eurovision" (1994) (Supervisor - Doctor of Art History, Professor Grigoriy R. Konson).

Great attention was paid to The Art of Cinema: "Movie Music: Directions of Research in Russian and World Art History (in the Case of Studying Approaches of European-American and Soviet-Russian Schools)" by Tatiana K. Egorova - Doctor of Art History, Professor of the Multimedia Directing Department, the St. Petersburg Humanitarian University of Trade Unions, Lecturer of the Cinema and TV Higher Courses, the Gerasimov AllRussian State Institute of Cinematography, Editor-in-Chief of the Monthly Academic Journal "Musicology", "2016 Snow Western: Triumph of Genre in Historical Perspective (from A. De Toth's and Corbucci's Films to K. Tarantino's and A. G. Iñarritu's Motion Pictures)" by Artem N. Zorin - Doctor of Philology, Professor of the General Literary Studies and Journalism Department at the Saratov State University named after N.G. Chernyshevsky, Professor of the Department of Acting, the Theater Institute of Saratov State Conservatory named after L.V. Sobinov, "Methodology and Logic of Film Studies - on Problem of Evolution of Humanities Experience (on the Basis of Ricciotto Canudo Syncretic Traditions Study in the Context of Early Avant-Garde Ideas)" by Andrey 
M. Shemyakin - PhD in Philology, Associate Professor, Leading Scientific Researcher of Cinema Art Research Institute, the Gerasimov All-Russian State Institute of Cinematography, Vice-President of Russian Guild of Film Critics.

In general, there was a panorama of great scientific achievements that revealed the path to higher levels of human consciousness: the problems of saving the cultural heritage and the search for new humanitarian values were integrated in a unique transdisciplinary experience of participants of open forum.

For citation:

(C) Konson, G., 2017

Konson, G. (2017). The International Scientific Conference "Art History in the Context of Other Sciences in Russia and Abroad: Parallels and Interactions". RUDN Journal of Psychology and Pedagogics, 14 (3), 353-359. DOI 10.22363/2313-1683-2017-14-3-353-359

\section{Bio Note:}

Grigoriy R. Konson - Doctor of Art History, Head of Department of Applied Doctoral Studies and Preparation of Research Assistants, Professor of Department of Sociology and Philosophy of Culture, Russian State Social University (Moscow, Russia). E-mail: gkonson@yandex.ru

\section{Для цитирования:}

Консон Г.Р. Международная научная конференция «Искусствоведение в контексте других наук в России и за рубежом: параллели и взаимодействия» // Вестник Российского университета дружбы народов. Серия: Психология и педагогика. 2017. Т. 14. № 3. С. 353-359. DOI 10.22363/2313-1683-2017-14-3-353-359

\section{Сведения об авторе:}

Консон Григорий Рафаэльевич - доктор искусствоведения, профессор, начальник отдела прикладной докторантуры и подготовки научных кадров в докторантуре Российского государственного социального университета (Москва, Россия). E-mail: gkonson@yandex. $\mathrm{ru}$ 